\title{
MANUAL OF PRACTICES IN PHYSICAL EDUCATION IN PROFESSIONAL AND TECHNOLOGICAL EDUCATION USING THE FREE APPLICATION EFE - EPTFIS
}

\section{ORIGINAL ARTICLE}

VIANA, Valderi Nascimentoํ, FECURY, Amanda Alves², OLIVEIRA, Euzébio de ${ }^{3}$, DENDASCK, Carla Viana ${ }^{4}$, DIAS, Claudio Alberto Gellis de Mattos ${ }^{5}$

VIANA, Valderi Nascimento. Et al. Manual of Practices in Physical Education in Professional and Technological Education Using the Free Application Efe Eptfis. Revista Científica Multidisciplinar Núcleo do Conhecimento. Year 06, Ed. 04, Vol. 05, pp. 65-76. April 2021. ISSN: 2448-0959, Acess Link: https://www.nucleodoconhecimento.com.br/education-physics-en/manual-ofpractices, DOI: 10.32749/nucleodoconhecimento.com.br/education-physicsen/manual-of-practices

\section{SUMMARY}

The application, EFE-EduFisEPT, acts as a support for physical education school activities, using historical-critical pedagogy occurs the confrontation of the scientific knowledge of the teacher with the empirical knowledge of the students, causing the development of a new vision and action in society. The purpose of this manual is to

\footnotetext{
${ }^{1}$ Physical Educator, Specialist in Exercise Physiology and Sports Nutrition (FAMA), Student of the Graduate Program in Professional and Technological Education (PROFEPT IFAP).

${ }^{2}$ Biomedical, PhD in Tropical Diseases, Professor and researcher of the Medical Course of Macapá Campus, Federal University of Amapá (UNIFAP).

${ }^{3}$ Biologist, PhD in Tropical Diseases, Professor and researcher of the Physical Education Course, Federal University of Pará (UFPA).

${ }^{4}$ Theologian, PhD in Clinical Psychoanalysis. He has been working for 15 years with Scientific Methodology (Research Method) in the Scientific Production Guidance of Master's and Doctoral students. Specialist in Market Research and Research focused on health.

${ }^{5}$ Biologist, PhD in Theory and Behavior Research, Professor and researcher of the Chemistry Degree Course of the Institute of Basic, Technical and Technological Education of Amapá (IFAP) and the Graduate Program in Professional and Technological Education (PROFEPT IFAP).
}

RC: 84005

Disponível em: https://www.nucleodoconhecimento.com.br/education-physics- 
guide the physical education teacher about the content and practices for physical education classes in EPT and about the functionality of the free Application EFE EPTFis. With its simple interface, the use of the application becomes easy and with intuitive functionality. This educational product exists as a support for the teacher to develop a more critical physical education, which understands the student beyond the biological being, that is, a social, political, cultural and historical being. In which each class, the student can understand that the content presented is linking to various dimensions of reality, contributing to a society vision based on values and attitudes towards the common goal: knowledge to generate fewer exclusions and discriminations.

Keywords: Physical Education, Practice, EPT, Training

\section{INTRODUCTION}

The application, EFE-EduFisEPT, was thought of as support for physical education school activities, aiming to work this curricular component in its entirety, thus providing a human, integral and omnilateral training to high school students of professional and technological education (EPT) (VIANA and DIAS, 2020).

Thus, using historical-critical pedagogy, the teacher's scientific knowledge is confronted with the empirical knowledge of the students, causing the development of a new vision and action in society (SILVA, 2017; ANDRADE et al., 2020).

In addition to pedagogical support, the application serves as a means of disseminating scientific knowledge, because all classes are based on this form of knowledge. Being an application, there is a greater ease of access from any part of the world (via mobile phone devices, tablets, computers and the like), making this content accessible, bringing the user closer to the scientific community, updating their knowledge. It encourages the user to be a connoisseur and have a greater interest to perform a differentiated pedagogical work (SANTOS et al., 2018).

RC: 84005

Disponível em: https://www.nucleodoconhecimento.com.br/education-physics- 


\section{GOAL}

Guide the physical education teacher about the content and practices for physical education classes in EPT and about the functionality of the free Application EFE EPTFis

\section{MATERIALS AND METHODS}

The app described here can be downloaded for free https://play.google.com/store/apps/details?id=com.ifap.efe (Play Store), exclusively for Android. The full content can be accessed for free at the https://www.edufisept.com.br/ .

\section{THE APPLICATION AND ITS CONTENTS}

\section{THE APPLICATION}

The application was designed, as well as the website, to give the professional who works (or not) with Professional and Technological Education (EPT) a practical theoretical tool in order to contribute to the human, integral and omnilateral training of students (VIANA et al., 2020).

The step-by-step that follows seeks to facilitate the work of professionals who have less affinity with this type of technology.

RC: 84005

Disponível em: https://www.nucleodoconhecimento.com.br/education-physics- 
Figure 1 Shows the application input interface. To view the menu you must slide the screen from left to right.
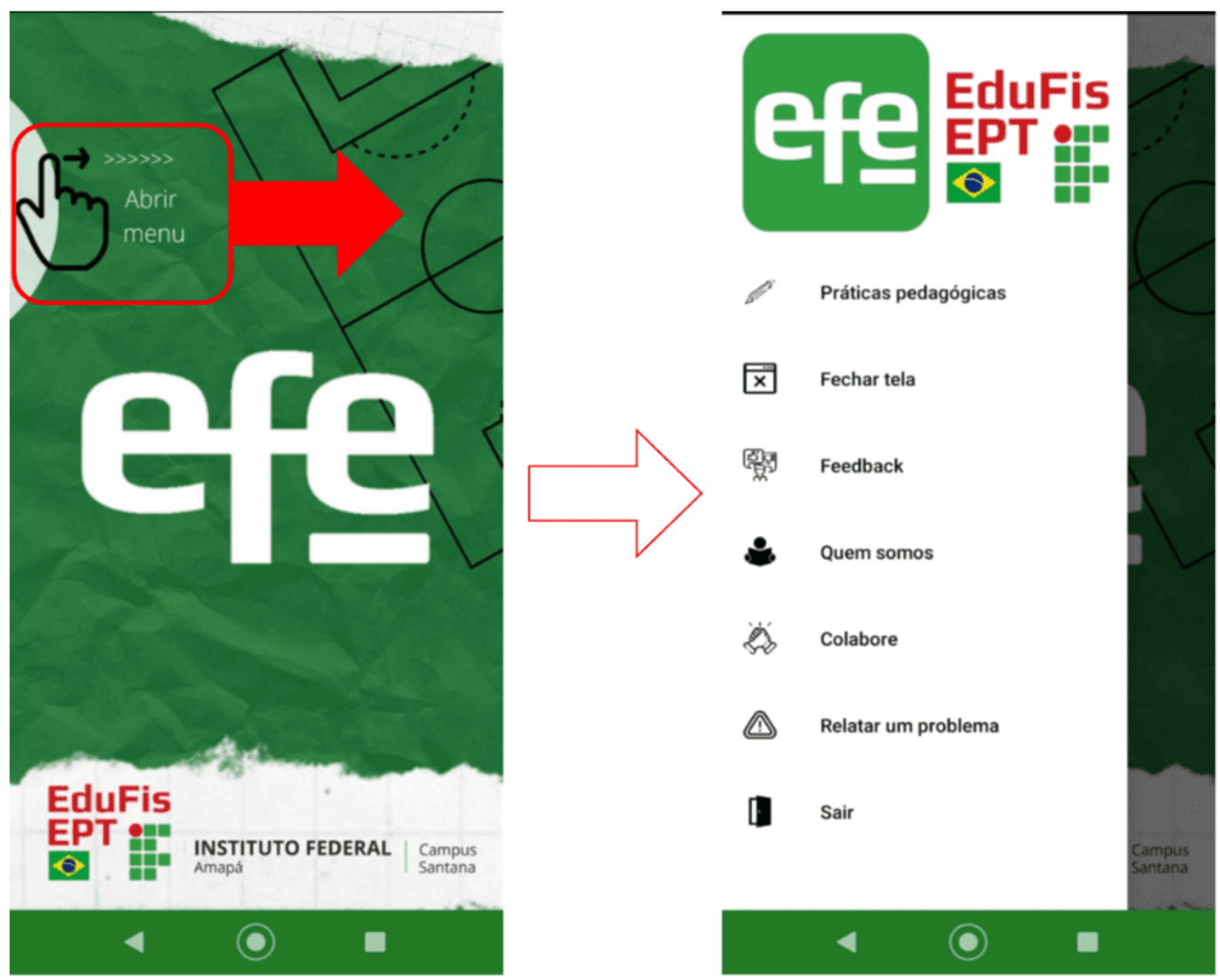

RC: 84005

Disponível em: https://www.nucleodoconhecimento.com.br/education-physics- 
Figure 2 Shows what happens when we click "Pedagogical Practices" in the menu. Another screen opens where you can select the practice type.
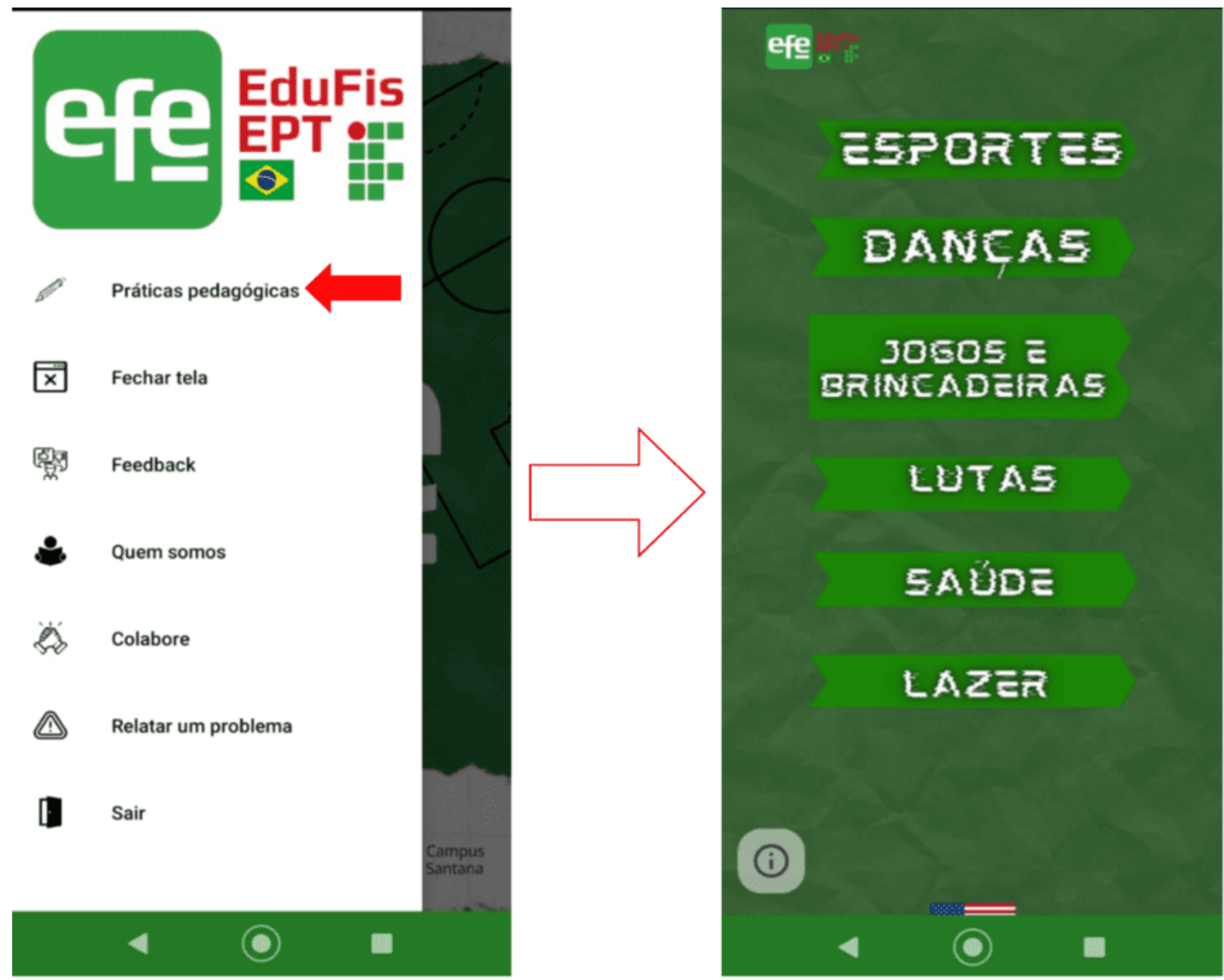

RC: 84005

Disponível em: https://www.nucleodoconhecimento.com.br/education-physics- 
Figure 3 Shows that by clicking on each item, there are buttons to access the theory that composes it and the practice itself, to be conducted with the students.

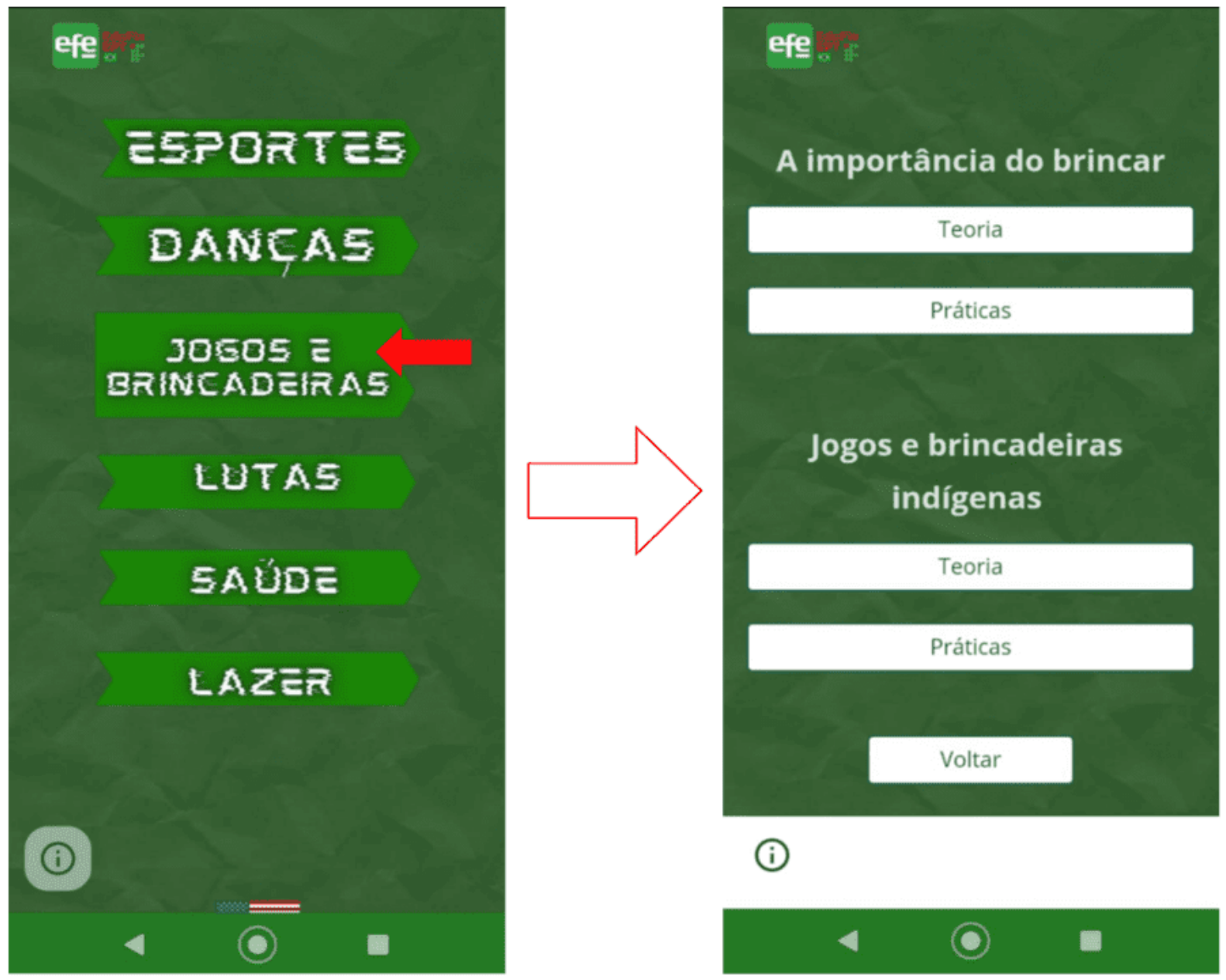

RC: 84005

Disponível em: https://www.nucleodoconhecimento.com.br/education-physics- 
Figure 4 Shows that by clicking on "Theory", a tab is made available with the reasoned theory and also video documentaries for better understanding of the practical part.

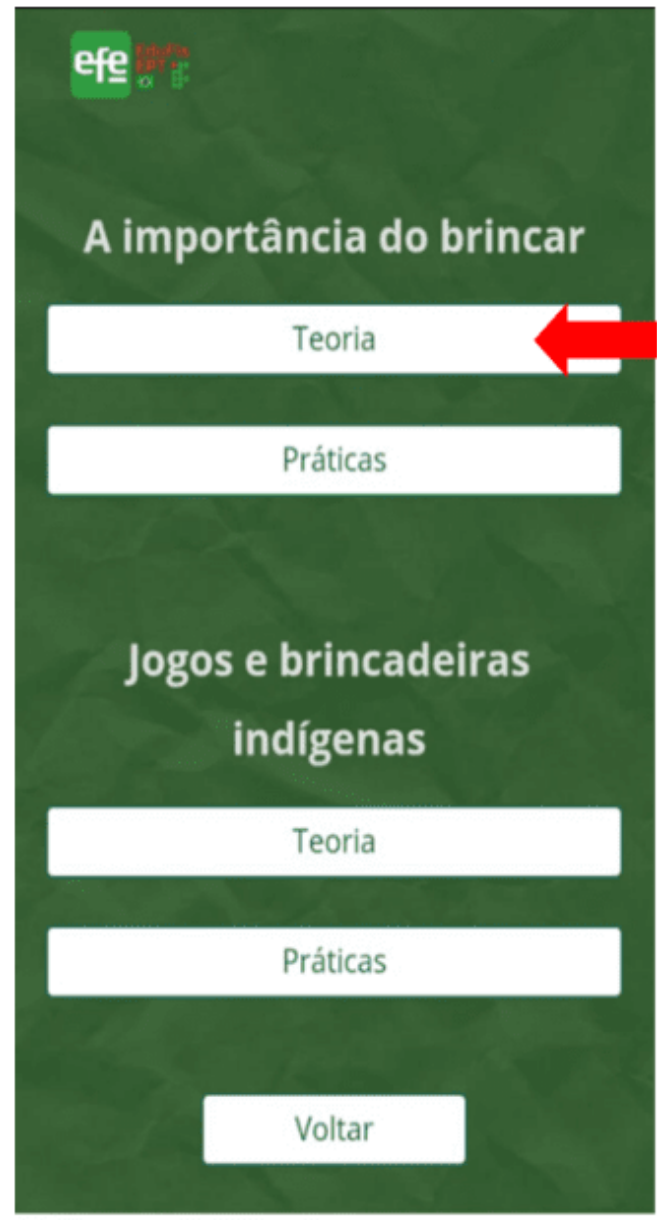

(i)

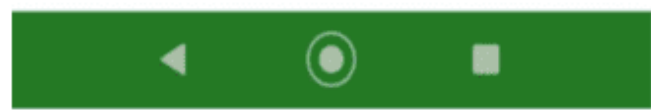

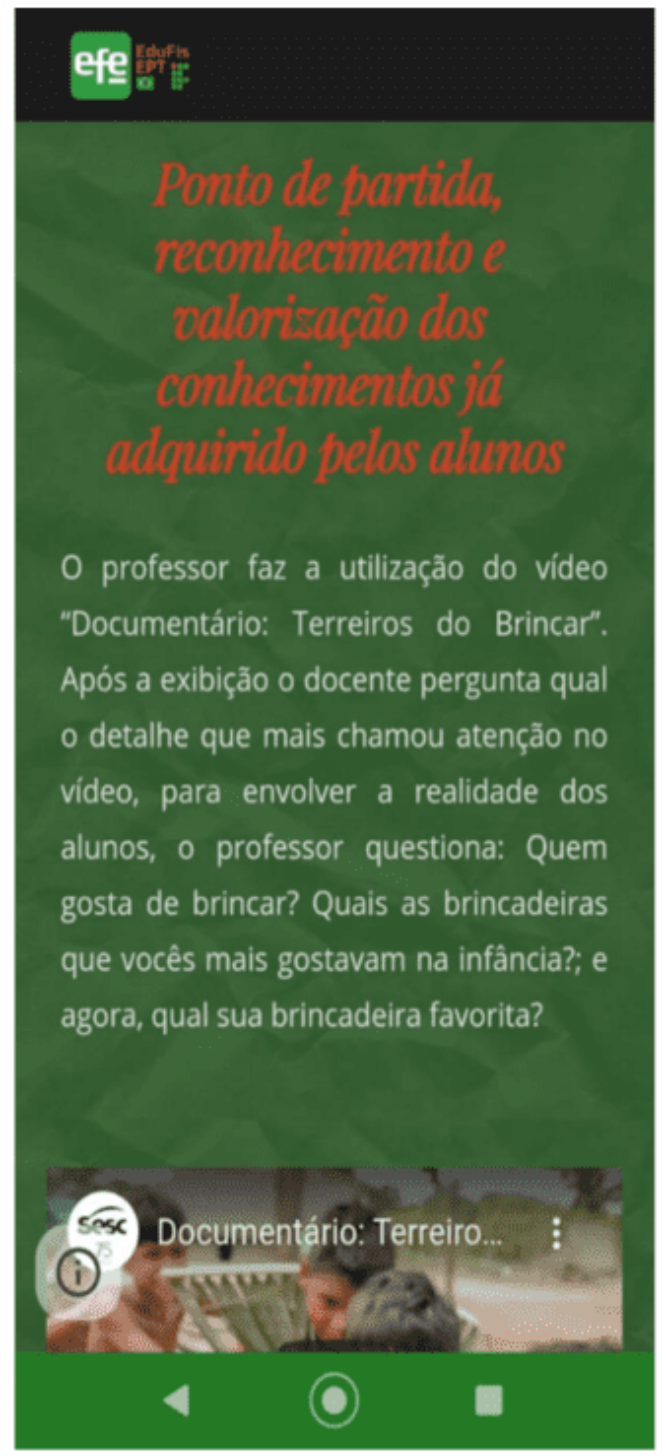

RC: 84005

Disponível em: https://www.nucleodoconhecimento.com.br/education-physics- 
Figure 5 Shows that by clicking "Practice", a new screen opens where several possible practices are presented.

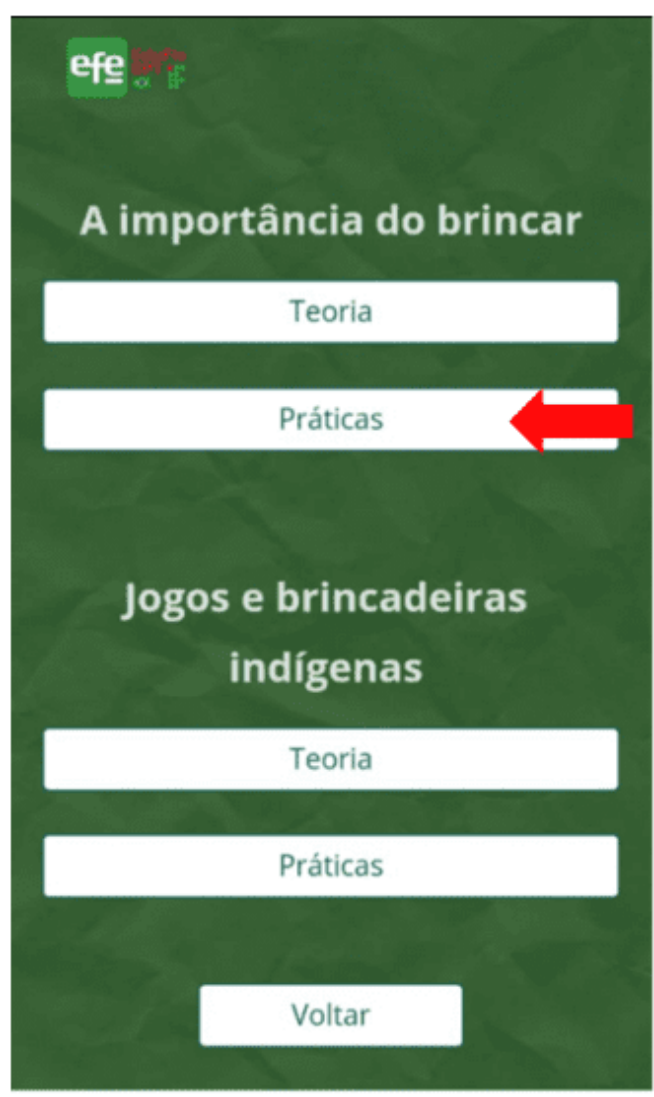

(i)

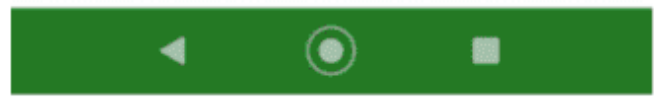

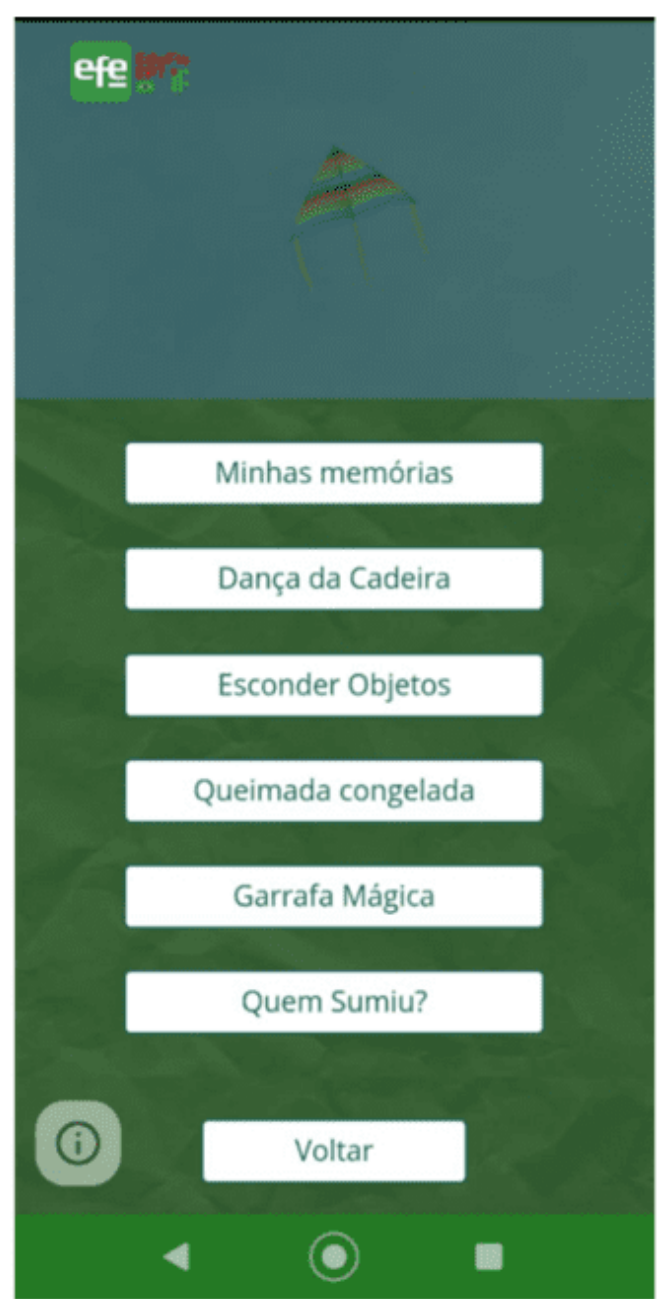

RC: 84005

Disponível em: https://www.nucleodoconhecimento.com.br/education-physics- 
Figure 6 Shows that by clicking, for example, "QueimadaCongelada " ( "dodgeball ") a new screen opens where for each practice there is an item that shows the resources needed for it, the detailed description, and a useful tip. This format repeats itself in all other application practices.
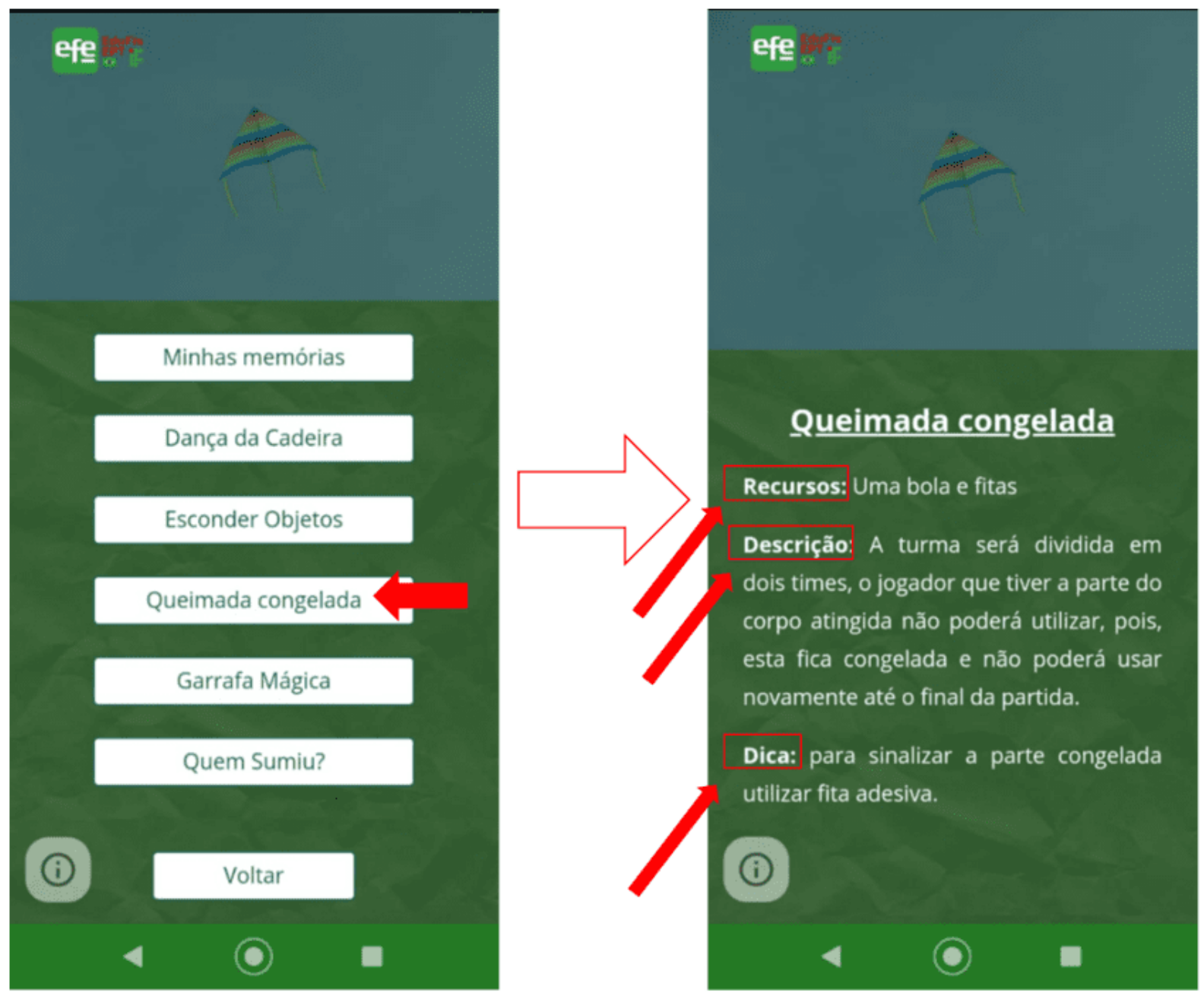

RC: 84005

Disponível em: https://www.nucleodoconhecimento.com.br/education-physics- 
Figure 7 Back to the home menu, by clicking on "Feedback", opens a screen where the user can participate in a data collection, important for continuation of the search of the author of the application, in this area of knowledge.

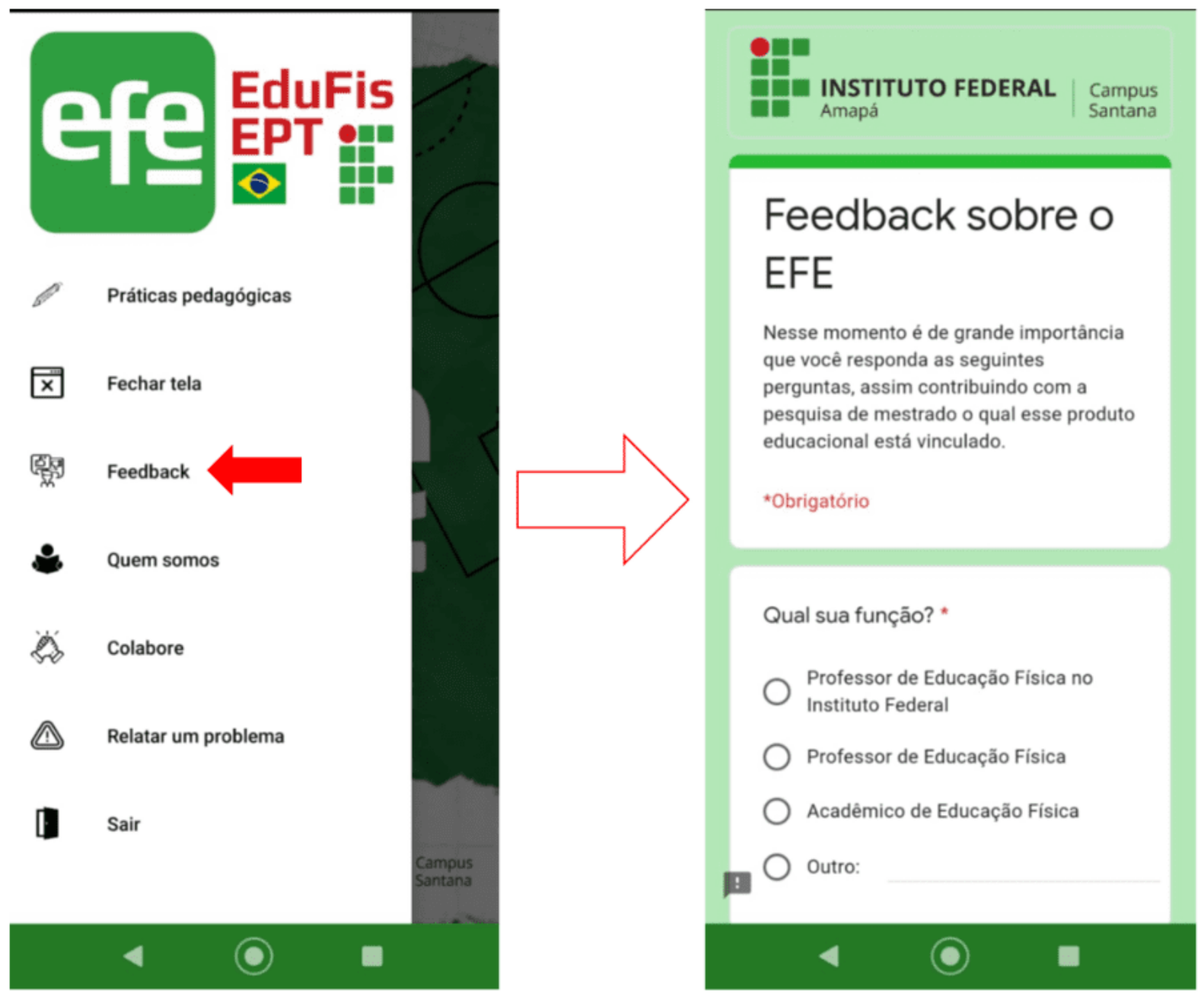

RC: 84005

Disponível em: https://www.nucleodoconhecimento.com.br/education-physics- 
Figure 8 By pressing the "Who We Are" button, still in the main menu, the user will have access to information from the authors of the application, as well as their resumes on the Lattes Platform.
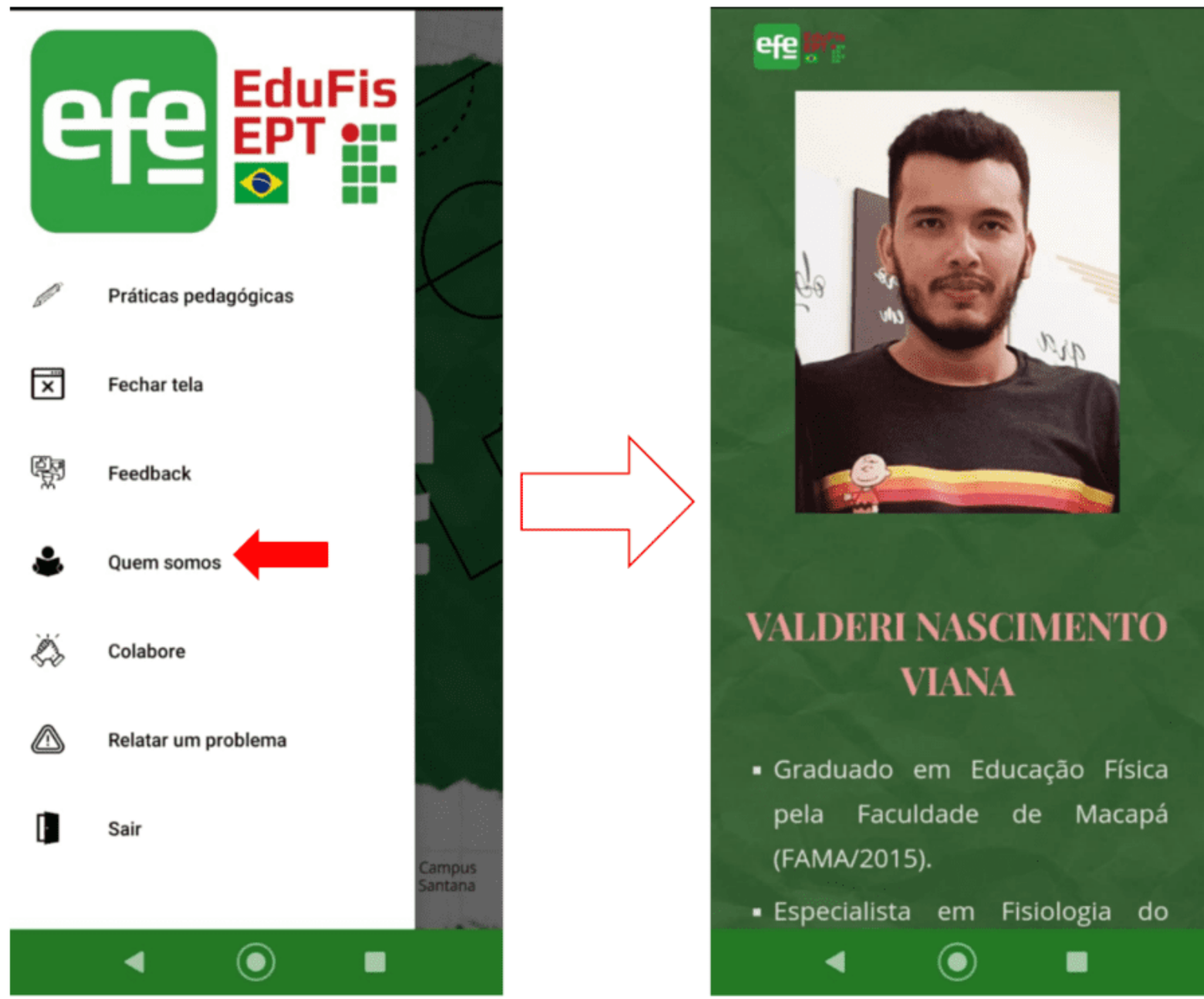

RC: 84005

Disponível em: https://www.nucleodoconhecimento.com.br/education-physics- 
Figure 9 In the menu, by clicking on "Collaborate", the user can collaborate in improving knowledge within this APP and on the website, sending in PDF or DOC format, with its own pedagogical practice and with evaluations directed by the application. It is taken into account that knowledge is not built in a solitary way.
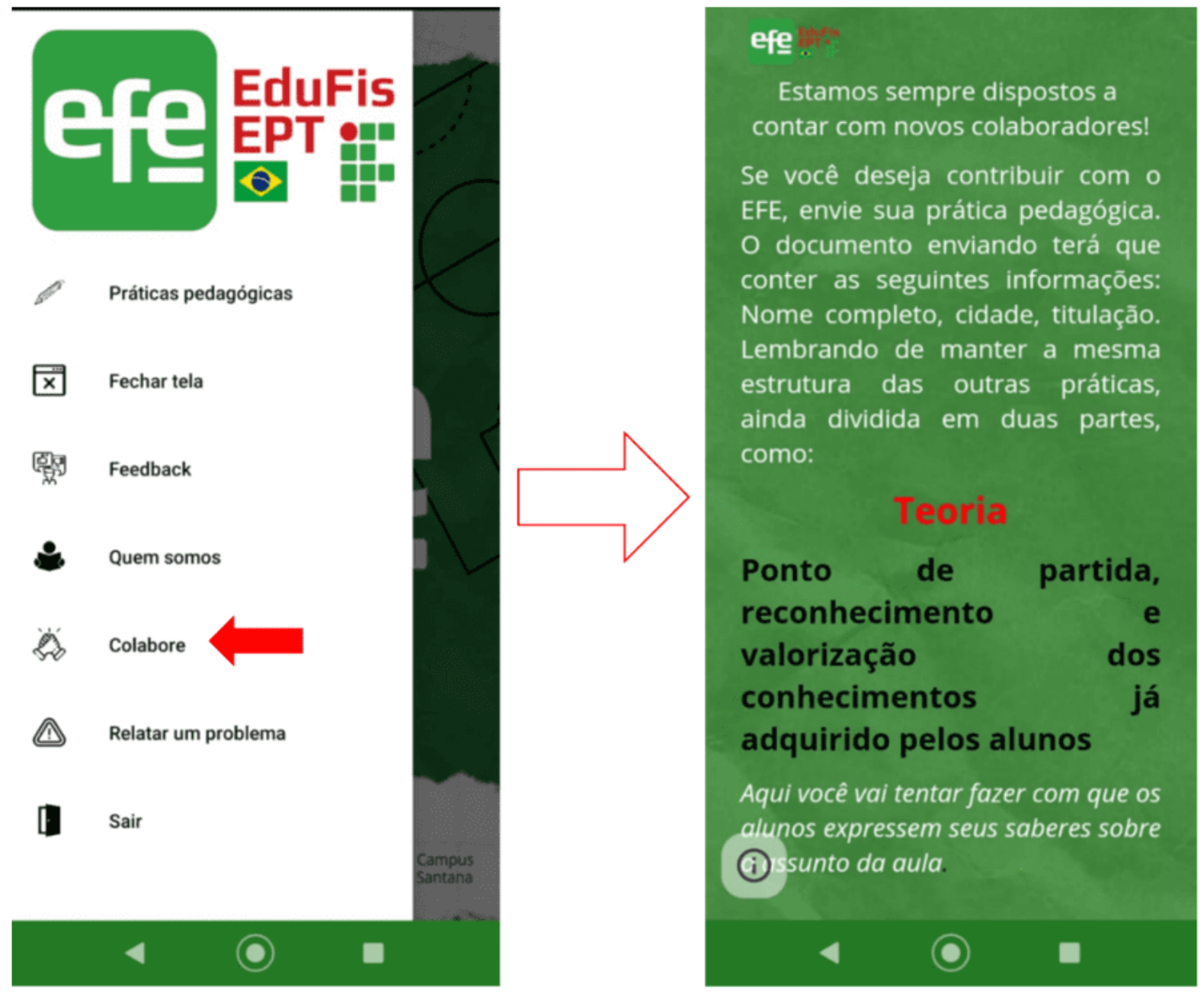

RC: 84005

Disponível em: https://www.nucleodoconhecimento.com.br/education-physics- 
Figure 10 In the menu you can still click to "Report a problem" in the application, click to "Close Window" or even click to "Exit".

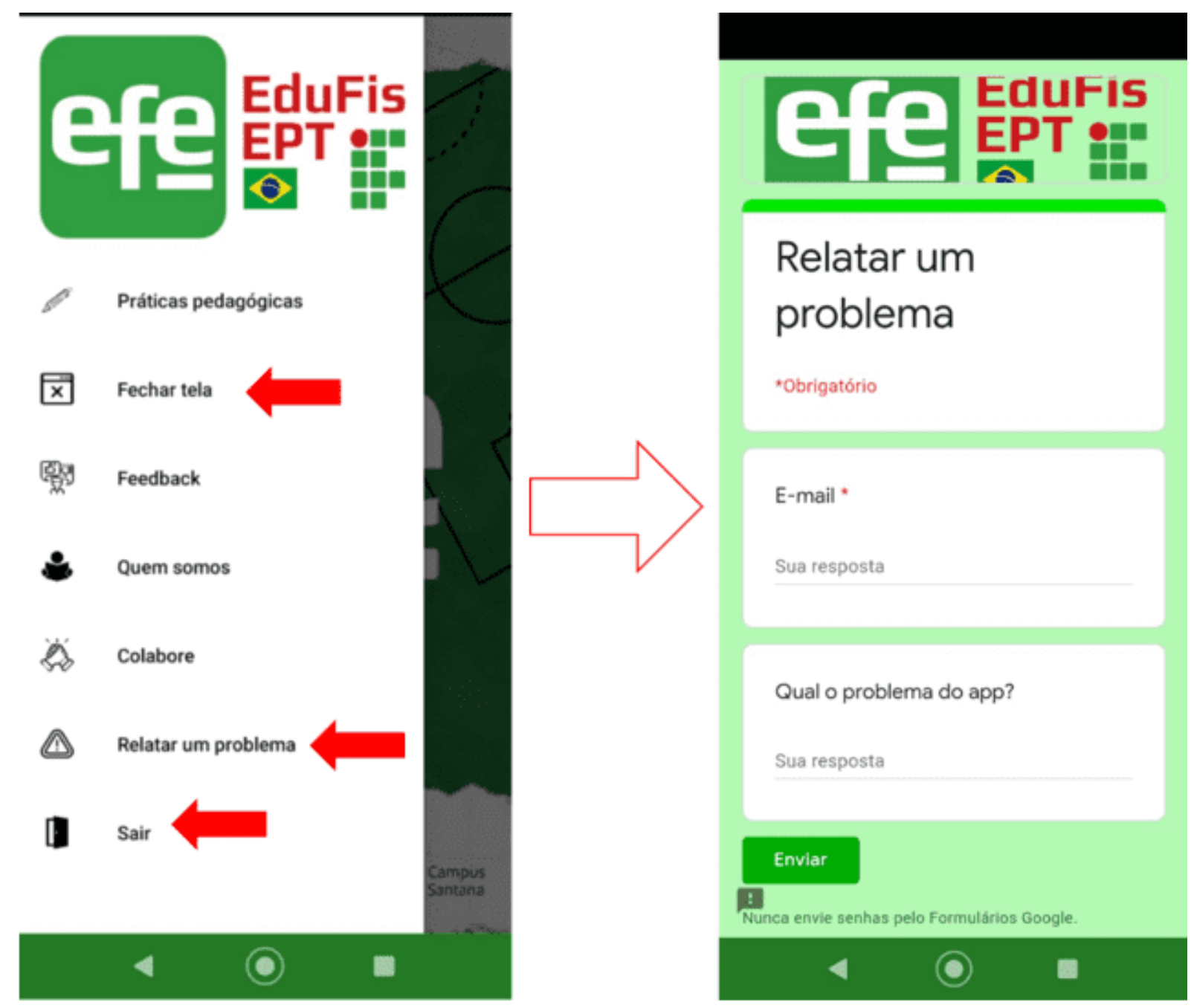

\section{THE CONTENT}

With easy and fast access through the Android application or through the website, the content has the ambition to show the theoretical part of human, integral and omnilateral training of all practical activity available.

RC: 84005

Disponível em: https://www.nucleodoconhecimento.com.br/education-physics- 
For this, it had a theoretical framework researched by the author during his stricto sensu graduate program, as well as the practice also derived from research, much carried out at the regional level.

Figure 11 Shows part of the theory within the item "Games and games".

\section{Jogos-e:brincadeiras?l}

Teoriaq

Ponto de partida, reconhecimento e valorização dos conhecimentos já adquirido pelos alunos

ฯ

O professor faz a utilização do vídeo "Documentário:- Terreiros do- Brincar". (https://www.youtube.com/watch?v=29yJW7XQUws- -). Após· a- exibição- o- docentepergunta qual o detalhe que mais chamou atenção no vídeo, para envolver a realidade dos alunos, o professor-questiona:-Quem gosta-de brincar?-Quais as brincadeiras que vocêsmais gostavam na infância?; e-agora, qual sua brincadeira favorita?

\section{Como pratica-social, questões que podem'ser resolvidas/debatidas} com o auxilio deste conteúdo. sugestões das dimensões teórico-práticas:-1ा

-Conceitual: O que-são-brincadeiras? -

- Cultural: $\mathrm{O}$ brincar-é-só coisa de criança? $\uparrow$

RC: 84005

Disponível em: https://www.nucleodoconhecimento.com.br/education-physics- 
-Psicológica/Histórica:-Qual-a-importância-do-brincar?

-Social:Por-que na-vida-adulta-somos-obrigados-a esquecer-as-brincadeiras?-

ๆ

Encaminhamento-metodológico para-a-explicação-do-conteúdo

Exibição-integral-ou parcial- do- documentário- "Tarja-Branca". - Disponivel-em. https://www.videocamp.com/pt/campaigns/quarentena-believe-

tarjabranca/player?special_id $=84100 \ldots$

O professor-vai fazer uma reflexão sobre o documentario e abordar assuntos como: brincadeira e a vida adulta; como - mercado-de trabalho-subtrai-das pessoas os momentoslúdicos-e-a-importância-dessa-pratica-para-a-saúde, fazendo-sempre-uma-ligação-com-ovideo exibido -1

\section{Formação,-atitudes-e-valores}

Ao final, o aluno tenha a atitude de perceber que mesmo deixando a infäncia nunca. parou-de-brincar, apenas -mudou- 0 -modo-e formas. Durante essa pratica-trabalha-com-0. aluno-a-cooperação, uniâo, senso-critico-e-criatividade.

RC: 84005

Disponível em: https://www.nucleodoconhecimento.com.br/education-physics- 
Figure 12 Shows some of the practices researched and described within the item "Games and games", always subdivided into "Resources" (necessary to assemble the practice), "Description" (method or rule to follow for the practice to work) and "Tip" (always another view on the practice).

\section{Minhas'memórias" \\ I \\ Recursos:-folha-de-A4, canetas}

Descrição: Em sala, -solicitar dos alunos que em uma folha-de-A4 faça um resgate de -suasmemorias as mais antigas, clara e-alegre, momentos de brincadeiras-de-sua infäncia. Podeser um brinquedo, um momento-especifico-como: uma-viagem, uma festa, férias. E-comisso, construir-a partir-dessas-lembranças como elas -se-conectam com-sua-vida-atual. -

Dicas:- Caso-0 aluno tenha-algum - registro,-no-grupo- de-WhatsApp-os-alunos-podemmandar a foto junto com um audio (Possivel ensino remoto), para-isso, o professor precisamarcar-um-dia-especifico.- Ou-pode-ser-feito-em-sala-de-aula, - o-qual-cada-um-leva-seuregistro-e-comenta- 9

\section{Dança'da.Cadeira,}

Recursos:-Cadeiras, caixa-de-som -

Descrição:- Será - formado - uma-roda-com-as - cadeiras-e - os alunos ficarão-a- sua-volta, contendo-uma-cadeira-a-menos que-o-número-de participantes. Ao-som-da-música-osalunos-vão-andar-ao-redor-da-roda-(dançando-no-ritmo-da-música)- Quando-a-músicapausar-cada-integrante-ocupa-uma-cadeira, - sempre-sobrando um-sem, ficando-fora-dadança.-A cada nova rodada fica sempre com uma cadeira a menos até sobrar apenas-umae-dois-alunos, que tentaram ocupá-1a, tornando-se-assim, - o vencedor. -

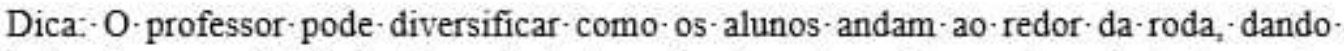
instruções como: Mais rápido; mais lento; andar-de costas; mão na cabeça; indo de acordo. com-a-criatividade-do professor. .

RC: 84005

Disponível em: https://www.nucleodoconhecimento.com.br/education-physics- 


\section{Quem·Sumiu?·}

Recursos:-Tecido, sala-de-aulaף

Descrição:-Em-sala-de-aula-ou-na-quadra-um-aluno-será-escolhido, antes-de-ter-os-olhosvendados, -vai-olhar para-a turma, - logo-depois-ficar-de-costas e-será-vendado, enquantoisso um aluno-selecionado-sai-do-local, 0 -aluno-com 05 -olhos cobertos-vira-de frente paraturma e tira-a-venda, com isso, terá que adivinhar quem sumiu do local - O que estava foraretorna e ocupa-o-lugar de quem deveria descobrir - 0 -integrante que estava-faltando. -

Dica: $O$-professor-pode autorizar-até-3 - características-do-aluno que-sumiu, tal-duvidasendo respondida pelos-alunos-da-turma-f

\section{Esconder-Objetos,}

Recursos:-20-Bolinhas-de plástico, -1

Descrição:A-turma-será-dividida-em-2-times. Uma-equipe-sai-da-sala-e pela-quadra-oupor-determinado espaço-dentro da-escola-tem que-esconder-os-objetos-(dentro-de-uns-3. minutos). Otime que ficou na-sala aguardando quando autorizado pelo professor -sai paraprocurar-os-objetos, por-um-tempo-limitado-Cada-objeto-encontrado-é-marcado-umapontuação para-o time, essa pontuação pode-ser definida pelas-cores-das bolinhas. -

\section{CONCLUSIONS}

With its simple interface, the use of the application becomes easy and with intuitive functionality. This educational product exists as a support for the teacher to develop a more critical physical education, which understands the student beyond the biological being, that is, a social, political, cultural and historical being. In which each class, the student can understand that the content presented is linking to various dimensions of reality, contributing to a society vision based on values and attitudes towards the common goal: knowledge to generate fewer exclusions and discriminations.

\section{REFERENCES}

RC: 84005

Disponível em: https://www.nucleodoconhecimento.com.br/education-physics- 
ANDRADE, L C; ANDRADE, J.S.D; ALMEIDA S.M. Pedagogia histórico-crítica e Educação Física: o ensino das práticas corporais de aventura nos anos iniciais. Motrivivência, v. 32, n. 63, p. 01-15, 2020.

SANTOS, L. S; PORTO, C. D.; OLIVEIRA, K. E. J. Whatsapp e ciência-a conectividade científica por meio da divulgação. C\&D-Revista Eletrônica da FAINOR, v. 11, n. 2, p. 271-289, 2018.

SILVA, M. B. Contribuições Da Educação Física Escolar Para A Formação Omnilateral Do Ser Social: Uma Reflexão À Luz Da Psicologia Histórico-Cultural E Da Pedagogia Histórico-Crítica. Germinal: Marxismo e Educação em Debate, v. 9, n. 2, p. 249, 2017.

VIANA, V. N. et al. Quadras de esportes em condições de uso adequado no Brasil: influência no ensino-aprendizagem nas aulas de Educação Física (2015). Research, Society and Development, v. 9, p. e239985704-14, 2020.

VIANA, V. N.; DIAS, C. A. G. M. Educação Física e EPT. São Paulo SP: Centro de Pesquisa, 2020. 45p. Disponível em: < https://www.nucleodoconhecimento.com.br/livros/educacao/educacao-fisica-e-ept >.

DOI: 10.32749///educacao/educacao-fisica-e-ept ISBN: 978-65-86069-90-7

Submitted: April, 2021.

Approved: April, 2021.

RC: 84005

Disponível em: https://www.nucleodoconhecimento.com.br/education-physics- 